\title{
High incidence of late infective endocarditis in bovine jugular vein valved conduits
}

Ziv Beckerman, MD, Luis E. De León, MD, Rodrigo Zea-Vera, MD, Carlos M. Mery, MD, MPH, and

Charles D. Fraser, Jr, MD

\section{ABSTRACT}

Background: Bovine jugular vein (BJV) grafts (Medtronic, Inc, Minneapolis, Minn) are used to restore right ventricle-to-pulmonary artery continuity. Recent studies have associated these grafts with the development of infective endocarditis. The purpose of this study was to report the incidence of endocarditis in BJV grafts.

Methods: All BJV grafts placed in the right ventricle-to-pulmonary artery position between 2001 and 2017 at our institution were included. Freedom from endocarditis was analyzed using the Kaplan-Meier method and parametric survival regression models.

Results: Overall, 228 patients underwent placement of 253 BJV grafts. The median duration of conduit follow-up was 6 years ( 5 months to 14 years). Twenty-five conduits developed endocarditis, yielding an incidence of $10 \%$ at a median of 7.5 years after surgery. Median duration of symptoms before the diagnosis of endocarditis was 21 days (3-180 days). The most common infectious agents were viridans streptococci $(\mathrm{n}=13 ; 52 \%)$. Freedom from endocarditis at 5 and 10 years was $97 \%$ and $77 \%$, respectively. After controlling for confounders, BJV grafts had a higher incidence of endocarditis compared with homografts $(P<.001)$. Twenty-three $(92 \%)$ of the conduits that developed endocarditis were managed surgically, with no mortality.

Conclusions: The incidence of late endocarditis affecting BJV is high. Increased surveillance and a high index of suspicion for endocarditis are warranted in patients who have undergone implantation of BJV grafts, especially if the graft has been in place for more than 7 years. When infective endocarditis has been diagnosed in these grafts, surgical replacement is recommended, with excellent outcomes. (J Thorac Cardiovasc Surg 2018;156:728-34)

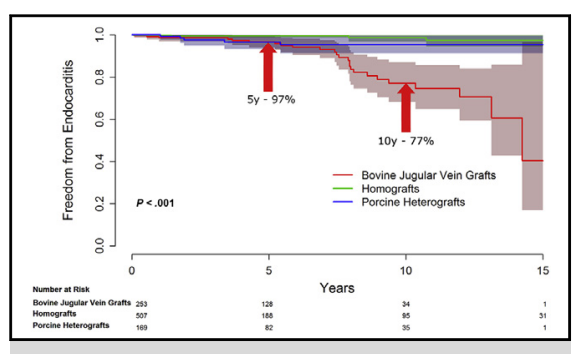

Kaplan-Meier curves depicting freedom from endo carditis according to conduit type.

\section{Central Message}

$\overline{\text { Bovine jugular vein grafts used to restore right }}$ ventricle-to-pulmonary artery continuity were shown to have a $10 \%$ incidence of endocarditis at a median of 7.5 years after surgery.

\section{Perspective}

Bovine jugular vein grafts are routinely used to restore right ventricle-to-pulmonary artery continuity. In this article we report on a long-term follow-up of 253 bovine jugular vein grafts. We encountered a $10 \%$ incidence of endocarditis at a median of 7.5 years after surgery. Freedom from endocarditis at 10 years was only $77 \%$. This high incidence of late endocarditis is concerning and warrants intervention.

See Editorial Commentary page 735.
A large spectrum of congenital heart conditions require reconstruction of the right ventricle-to-pulmonary artery (RV-PA) continuity, which is usually achieved with the use of valved conduits. The question of the ideal RV-PA

\footnotetext{
From the Division of Congenital Heart Surgery, Texas Children's Hospital, and Department of Surgery, Baylor College of Medicine, Houston, Tex

This work was supported by departmental funding.

Received for publication July 5, 2017; revisions received March 6, 2018; accepted for publication March 7, 2018; available ahead of print May 9, 2018.

Address for reprints: Charles D. Fraser, Jr, MD, Congenital Heart Surgery, Texas Children's Hospital, 6621 Fannin St, MC19345H, Houston, TX 77030 (E-mail: CDFraser@texaschildrens.org).

$0022-5223 / \$ 36.00$

Copyright $₫ 2018$ Published by Elsevier Inc. on behalf of The American Association for Thoracic Surgery

https://doi.org/10.1016/j.jtcvs.2018.03.156
}

conduit has been extensively investigated, and needless to say a perfect RV-PA conduit does not exist.

In 1999, the Contegra bovine jugular vein (BJV) graft (Medtronic, Inc, Minneapolis, Minn) was proposed for right ventricular outflow tract reconstruction. The Contegra conduit is a glutaraldehyde fixed heterologous BJV graft, containing a naturally integrated trileaflet valve and natural sinus slightly larger in diameter than its lumen. Its preparation includes a final sterilization step, performed using a

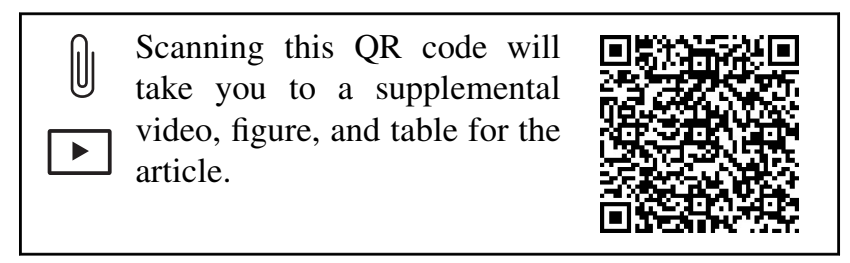




\section{Abbreviations and Acronyms \\ $\mathrm{BJV}=$ bovine jugular vein \\ $\mathrm{RV}-\mathrm{PA}=$ right ventricle-to-pulmonary artery}

proprietary sterilant that contains $1 \%$ glutaraldehyde and $20 \%$ isopropyl alcohol, in which the conduit is preserved and packaged until use. The Contegra is available in sizes between 12 and $22 \mathrm{~mm}$. Because of its encouraging initial results in clinical trials, it quickly gained popularity as a possible alternative to the homograft. ${ }^{2-4}$ Several studies have reported an unexpected occurrence of graft failure, ${ }^{5,6}$ whereas others have reported similar or even better behavior compared with homografts. ${ }^{7,8}$

In 2016 we published our experience with implantation of 792 valved conduits in the RV-PA position, among which 245 were BJV grafts. Despite finding that BJVs were associated with a lower risk for reintervention $(P<.0001)$ and replacement $(P=.0002)$ than homografts, $14 \mathrm{BJV}$ graft conduits developed endocarditis at a median of 7.5 years (34 days to 10 years) after surgery. After adjusting for other variables, the use of BJVs was found to be the sole significant risk factor associated with endocarditis and it was associated with a 9 times greater risk of endocarditis compared with homografts. ${ }^{9}$

Over the past 3 years we have encountered a concerning increasing incidence of late endocarditis in patients with BJV grafts. This concern has been raised by recent series as well. ${ }^{10-13}$ Accordingly, the goal of this study was to evaluate the incidence of late endocarditis in patients who underwent placement of bovine jugular vein grafts in the RV-PA position.

\section{METHODS}

The study cohort included all patients who underwent surgical placement of a BJV graft at Texas Children's Hospital between 2001 and 2017. The study was approved by Baylor College of Medicine's institutional review board (date and number of approval: September 2, 2016, H-15017), and informed consent was waived. All demographic and clinical data were retrospectively collected via review of all medical records, operative reports, procedure notes, discharge notes, and clinic notes. Follow-up was obtained through a combination of clinic notes and telephone interviews of patients, families, and referring physicians. Perioperative mortality was defined as death within 30 days after surgery or before hospital discharge.

For a subanalysis of data, comparing the risk of endocarditis between conduits, homografts (pulmonary and aortic), and porcine heterograft (Hancock bioprosthetic valved conduit; Medtronic, Inc) were also included. All homografts were cryopreserved and provided by LifeNet (Virginia Beach, Va), CryoLife (Kennesaw, Ga), or RTI/Alabama Tissue Bank (Birmingham, Ala).

Valved conduits arising from a morphological left ventricle in the setting of congenitally corrected transposition of the great arteries were included in the study. The cohort was divided into the following diagnostic groups: pulmonary atresia with ventricular septal defect with or without major aortopulmonary collaterals, truncus arteriosus, Ross procedure, and other (ie, history of nonconduit tetralogy of Fallot repair, absent pulmonary valve syndrome, pulmonary atresia with intact ventricular septum, double-outlet right ventricle, and transposition of the great arteries with pulmonary stenosis or atresia). Endocarditis was defined as possible or definitive on the basis of the modified Duke criteria. ${ }^{14}$ Pathologic diagnosis was defined as a positive culture from a vegetation or histopathology consistent with infective endocarditis.

\section{Data Analysis}

All analyses were performed for each conduit rather than for each patient. Descriptive analyses were performed for the entire cohort. Data are described as percentages and medians with ranges, as appropriate. Univariate analyses for freedom from endocarditis were performed using the Kaplan-Meier method and log rank test. The event endocarditis was registered when the diagnosis of endocarditis was made. For analysis of freedom from endocarditis, noninfected conduits were censored at the time of surgical replacement or placement of a transcatheter pulmonary valve. For patients who died, conduits were censored at the time of death.

To assess risk factors for endocarditis, parametric survival analysis models were created. Variables included were age, conduit size, diagnosis, genetic syndromes, and the conduit type (BJV grafts, homografts, and porcine heterografts). Because the analysis was done according to conduit rather than according to patients, events were modeled as repeated occurrences by including a variable of conduit placement versus replacement in the models. Results are reported as coefficients with standard errors and corresponding hazard ratios with $95 \%$ confidence intervals. A $P$ value $<.05$ was considered statistically significant. All analyses were carried out using SAS for Windows version 9.4 (SAS Institute Inc, Cary, NC).

\section{RESULTS}

A total of 228 patients underwent placement of $253 \mathrm{BJV}$ grafts (Table 1); 203 and 25 patients had 1 and 2 BJV grafts,

TABLE 1. Characteristics of patients who underwent conduit implantation

\begin{tabular}{|c|c|}
\hline Variable & Bovine jugular graft $(n=253)$ \\
\hline Male sex, n (\%) & $137(54)$ \\
\hline Syndrome, n (\%) & $66(26)$ \\
\hline Median weight (range), $\mathrm{kg}$ & $12(2-77)$ \\
\hline Median age (range) & $2 \mathrm{y}(15 \mathrm{~d}$ to $45 \mathrm{y})$ \\
\hline \multicolumn{2}{|l|}{ Age groups, n (\%) } \\
\hline Neonates and infants & $67(26)$ \\
\hline 1 to 4 years old & $101(40)$ \\
\hline 5 to 9 years old & $37(15)$ \\
\hline 10 to 18 years old & $42(17)$ \\
\hline Older than $18 \mathrm{y}$ & $6(2)$ \\
\hline \multicolumn{2}{|l|}{ Diagnosis, $\mathrm{n}(\%)$} \\
\hline PA/VSD & $92(36)$ \\
\hline Truncus & $67(27)$ \\
\hline Ross procedure & $17(7)$ \\
\hline Other* & $77(30)$ \\
\hline \multicolumn{2}{|l|}{ Conduit sequence, $\mathrm{n}(\%)$} \\
\hline Primary placement & $131(52)$ \\
\hline Replacement & $122(48)$ \\
\hline Median conduit size, mm (range) & $16(12-22)$ \\
\hline
\end{tabular}




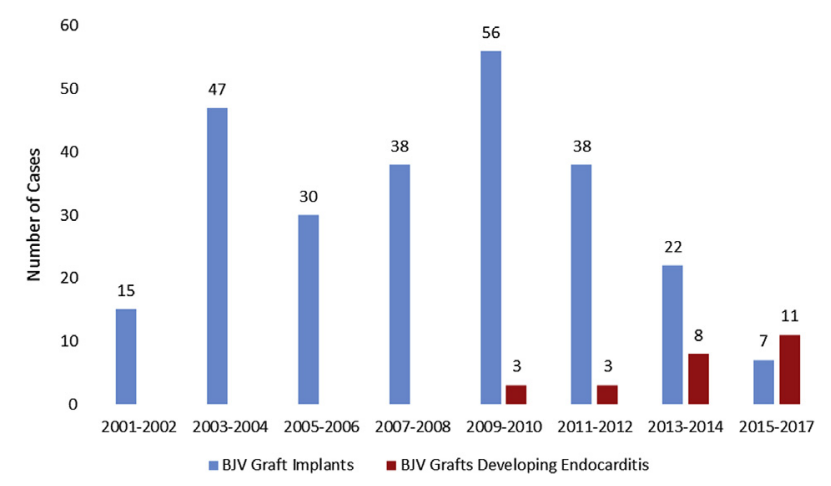

FIGURE 1. Implantation and development of endocarditis of bovine jugular vein $(B J V)$ grafts over time.

respectively. The median age at conduit placement was 4 years (range, 3 days to 54 years). The number of conduits implanted increased from 2001 to 2010, after which they gradually began to decrease (Figure 1). Among the 228 patients, $62(27 \%)$ had an identified genetic syndrome or chromosomal abnormality. During a median 6.5 years (range, 3 days to 16 years) of follow-up, 6 (2.6\%) of 228 patients died, including $2(0.9 \%)$ perioperative deaths, none of which were related to infective endocarditis. The summary of the deceased patients is shown in Table 2. A total of $131(52 \%)$ primary conduit placements and 122 $(48 \%)$ conduit replacements were performed. From the 122 conduit replacements, 44 were referred to our center after conduit placement at other institutions and 78 were performed after a previous conduit implantation at our center including: 53 homografts, 24 BJV conduits, and 1 porcine heterograft. The median duration of conduit follow-up was 6 years (range, 3 days to 14 years).

\section{Endocarditis}

During the follow-up period, 25 BJV grafts developed endocarditis at a median of 7.5 years (range, 34 days to 14 years) after surgery. Of the 25 patients who developed endocarditis, only $1(4 \%)$ patient had a dental procedure within the month before diagnosis. Median age at endocarditis was 13 (range, 1-21) years and $11(44 \%)$ were female. Patients exhibited clinical symptoms for a median duration of 21 days (range, 3-180 days) before the diagnosis of endocarditis was made. Four patients $(16 \%)$ were asymptomatic at the time of presentation, whereas $2(8 \%)$ presented in shock, the 19 remaining patients $(76 \%)$ had nonspecific symptoms such as low-grade fever or malaise. Endocardial involvement was present in 20 patients $(80 \%), 18(72 \%)$ had vegetations on echocardiography, 4 (16\%) had emboli, and $4(16 \%)$ had vascular phenomena. No patient presented with immunologic phenomena (Table E1).

Endocarditis was classified as definitive in $22(88 \%)$ and possible in $3(12 \%)$ according to Duke modified criteria for infective endocarditis. ${ }^{14}$ Blood cultures were positive in 22 patients $(88 \%)$ with infected conduits. The most common infectious agents were viridans streptococci $(\mathrm{n}=13$; $59 \%$ ). Other pathogens included methicillin-sensitive Staphylococcus aureus $(\mathrm{n}=3,14 \%)$, Haemophilus parainfluenzae $(\mathrm{n}=2 ; 9 \%)$, methicillin-resistant $S$ aureus $(\mathrm{n}=1$; $4.5 \%)$, Granulicatella adiacens $(\mathrm{n}=1 ; 4.5 \%)$, Cardiobacterium hominis $(\mathrm{n}=1 ; 4.5 \%)$, and Aggregatibacter actinomycetemcomitans $(\mathrm{n}=1 ; 4.5 \%)$. A pathologic diagnosis was made in 13 patients $(52 \%)$ with infected BJV grafts. In the remaining 10 conduits without pathologic diagnosis, a pathologic report was not available in 7 and signs of chronic inflammation and calcification were found in 3 .

The overall incidence of endocarditis among BJV grafts was $10 \%$ at a median follow-up of 7.5 years, compared with $0.8 \%$ (4 of 507) of the homografts and $2.9 \%$ (5 of 169) of the porcine heterografts, and it increased over time after 2010 (Figure 1). Five- and 10-year freedom from endocarditis rates among BJV grafts was $97 \%$, and $77 \%$, respectively, significantly different from that of homografts (Figure 2). After multivariable analysis, BJV grafts remained the only risk factor for developing endocarditis, with a hazard ratio of 15.7 (95\% confidence interval, 4.950.7; Table 3 and Figure E1).

The management of endocarditis was surgical in 23 $(92 \%)$ cases, and medical in $2(8 \%)$. Two patients who were managed medically exclusively with antibiotics had complete resolution of symptoms. Of the 23 surgically replaced infected conduits, $19(83 \%)$ were replaced with homografts, $3(13 \%)$ with BJV grafts, and $1(4 \%)$ with a porcine heterograft. Median duration of antibiotic therapy was 6 weeks (range, 4-11 weeks) for the 25 conduits that developed endocarditis. After endocarditis, there were no mortalities or recurrence of endocarditis at a median of 2 years (range, 1 month to 7 years), independent of treatment strategy.

\section{Replacement}

A total of $76(30 \%)$ BJV grafts required surgical replacement $(n=63 ; 83 \%)$ or transcatheter pulmonary valve implantation $(\mathrm{n}=13 ; 17 \%)$. Of those conduits that required replacement, $12(19 \%)$ were replaced with porcine heterografts, $25(40 \%)$ with homografts, $24(38 \%)$ with BJV grafts, and $2(3 \%)$ with other types of conduit. Five- and 10 -year freedom from replacement rates were $84 \%$ and $49 \%$, respectively. During the study period, 7 of the conduits had stents placed at a median of 3.3 years (range, 4 months to 9 years) after implantation, 2 of these conduits later developed endocarditis at 3 and 9 years, respectively, after stenting.

\section{DISCUSSION}

This study represents one of the largest singleinstitutional experiences with the use of BJV graft conduits for right ventricular outflow tract reconstruction. The main 
TABLE 2. Summary of mortalities

\begin{tabular}{|c|c|c|c|c|c|c|c|c|}
\hline Patient & $\begin{array}{c}\text { Age at } \\
\text { surgery }\end{array}$ & Diagnosis & Syndrome & $\begin{array}{c}\text { Associated } \\
\text { comorbidities }\end{array}$ & $\begin{array}{c}\text { Previous } \\
\text { surgery }\end{array}$ & Surgery & $\begin{array}{c}\text { Time } \\
\text { to death* }\end{array}$ & Cause of death \\
\hline 1 & $10 \mathrm{y}$ & CAVC, ToF & Trisomy 21 & Chronic renal failure & $\begin{array}{c}\text { Waterston } \\
\text { shunt }\end{array}$ & $\begin{array}{l}\text { ToF-CAVC repair with } \\
\text { PA reconstruction }\end{array}$ & $1.4 \mathrm{y}$ & $\begin{array}{l}\text { Septic shock due } \\
\text { to peritonitis }\end{array}$ \\
\hline 2 & $17 \mathrm{~d}$ & $\begin{array}{l}\text { Truncus } \\
\text { arteriosus }\end{array}$ & - & $\begin{array}{l}\text { Anomalous LCA } \\
\text { with IM course, } \\
\text { CHF }\end{array}$ & - & $\begin{array}{l}\text { Rastelli and aortic } \\
\text { valvuloplasty and } \\
\text { LCA reimplantation }\end{array}$ & $34 \mathrm{~d} \dagger$ & $\begin{array}{r}\text { Myocardial } \\
\text { ischemia }\end{array}$ \\
\hline 3 & $11 \mathrm{mo}$ & $\begin{array}{l}\text { L-TGA, } \\
\text { VSD, PS }\end{array}$ & - & $\begin{array}{l}\text { Extensive } \\
\text { intrapulmonary } \\
\text { AVMs }\end{array}$ & BDG & $\begin{array}{r}\text { Hemi Mustard } \\
\text { and Rastelli }\end{array}$ & $1 \mathrm{~d} \dagger$ & Heart failure \\
\hline 4 & $8 \mathrm{mo}$ & ToF-PA & Trisomy 21 & $\begin{array}{l}\text { Anomalous LAD } \\
\text { artery arising from } \\
\text { RCA, pulmonary } \\
\text { hypertension }\end{array}$ & - & $\begin{array}{l}\text { Rastelli and PA } \\
\text { reconstruction } \\
\text { and ECMO }\end{array}$ & $9 \mathrm{~d}$ & Heart failure \\
\hline 5 & $10 \mathrm{mo}$ & ToF-PA & - & - & BT Shunt & $\begin{array}{l}\text { Rastelli and PA } \\
\text { reconstruction }\end{array}$ & $1.3 \mathrm{y}$ & Pneumonia \\
\hline 6 & $1 \mathrm{y}$ & ToF-PA & CHARGE & $\begin{array}{l}\text { Tracheostomy, } \\
\text { G-tube dependency, } \\
\text { bilateral } \\
\text { cleft lip/palate }\end{array}$ & BT Shunt & $\begin{array}{l}\text { Rastelli and PA } \\
\text { reconstruction }\end{array}$ & $6 \mathrm{mo}$ & $\begin{array}{l}\text { Septic shock due } \\
\text { to NEC }\end{array}$ \\
\hline
\end{tabular}

$C A V C$, Complete atrioventricular canal; $T o F$, tetralogy of Fallot; $P A$, pulmonary artery; $L C A$, left coronary artery; $I M$, intramural; $C H F$, congestive heart failure; $L-T G A$, congenitally corrected transposition of the great arteries; VSD, ventricular septal defect; $P S$, pulmonary stenosis; $B D G$, bidirectional Glenn; $A V M s$, arteriovenous malformations; $T o F-P A$, tetralogy of Fallot with pulmonary atresia; $L A D$, left anterior descending; $R C A$, right coronary artery; $E C M O$, extracorporeal membrane oxygenation; $B T$, Blalock-Taussig; $N E C$, necrotizing enterocolitis; $C H A R G E$, coloboma, heart defects, atresia choanae, growth retardation, genital abnormalities, and ear abnormalities; $G$-tube, gastrostomy tube. *After surgical intervention. $\dagger$ Perioperative death.

finding of this study was an alarming $10 \%$ incidence of late endocarditis affecting BJV grafts (Video 1).

Because of its availability, easy manipulation in the operating room, and wide range of sizes, the BJV graft has gained popularity as an alternative option to homografts for the treatment of congenital heart defects, and valvular heart disease. ${ }^{4,15}$ Another potential advantage of this conduit is its longer durability, although this finding still

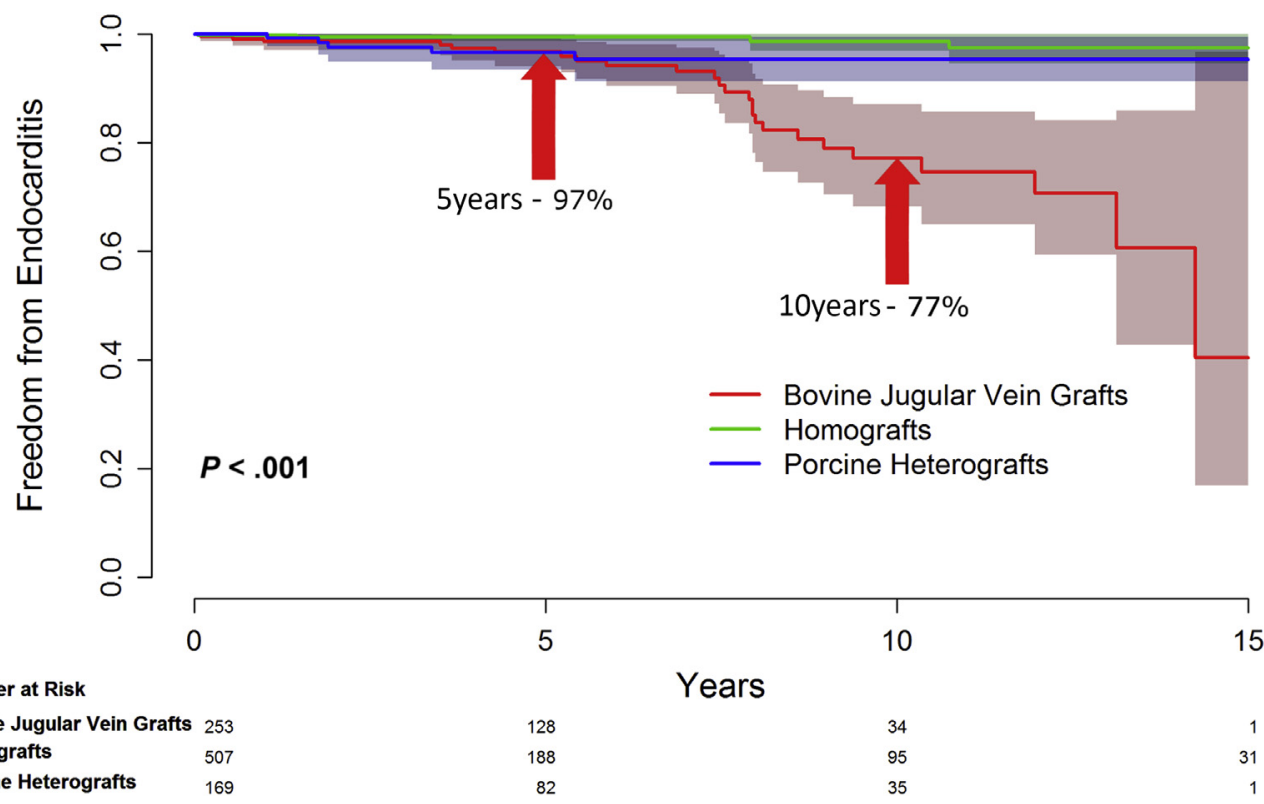

FIGURE 2. Kaplan-Meier curves depicting freedom from endocarditis according to conduit type. Bovine jugular vein grafts had a significantly higher incidence of endocarditis than homografts and porcine heterografts $(P<.001)$. The number of infected bovine jugular vein grafts drastically increases after 7 years of conduit implantation. 
TABLE 3. Multivariable analysis for development of endocarditis

\begin{tabular}{lccc}
\hline \multicolumn{1}{c}{ Covariate } & Coefficient \pm SE & HR $(\mathbf{9 5} \%$ CI) & $\boldsymbol{P}$ value \\
\hline Age, $y$ & $-0.02 \pm 0.05$ & $0.98(0.89-1.08)$ & .6249 \\
Conduit size, mm & $0.07 \pm 0.09$ & $1.07(0.9-1.27)$ & .435 \\
Syndrome & & & \\
$\quad$ No & $-0.48 \pm 0.49$ & $0.62(0.24-1.61)$ & .3245 \\
$\quad$ Yes & & & \\
Conduit Type & & Reference & \\
Homograft & & & \\
Bovine jugular grafts & $2.76 \pm 0.6$ & $15.74(4.89-50.69)$ & $<.0001$ \\
Porcine heterografts & $1.19 \pm 0.72$ & $3.28(0.79-13.51)$ & .1007 \\
Diagnosis & & & \\
PA/VSD & & Reference & \\
Truncus & $0.37 \pm 0.51$ & $1.45(0.53-3.98)$ & .4658 \\
Ross procedure & $0.54 \pm 0.72$ & $1.71(0.41-7.06)$ & .4598 \\
Others* & $0.79 \pm 0.46$ & $2.21(0.89-5.47)$ & .0861 \\
Initial conduit & & & \\
Yes & & Reference & \\
No & $0.17 \pm 0.44$ & $1.19(0.5-2.83)$ & .6998 \\
Z-Score & $0.01 \pm 0.21$ & $1.01(0.66-1.52)$ & .98 \\
\hline
\end{tabular}

$S E$, Standard error; $H R$, hazard ratio; $C I$, confidence interval; $P A / V S D$, pulmonary atresia with ventricular septal defect. *Includes history of nonconduit tetralogy of Fallot repair, transposition of the great arteries with pulmonary stenosis or pulmonary atresia, absent pulmonary valve syndrome, pulmonary atresia with intact ventricular septum, and double-outlet right ventricle.

remains controversial, with contradicting evidence in the literature. ${ }^{16-19}$ In a multi-institutional propensity-matched study of 107 infants with truncus arteriosus, Hickey and colleagues reported that BJV grafts were associated with a

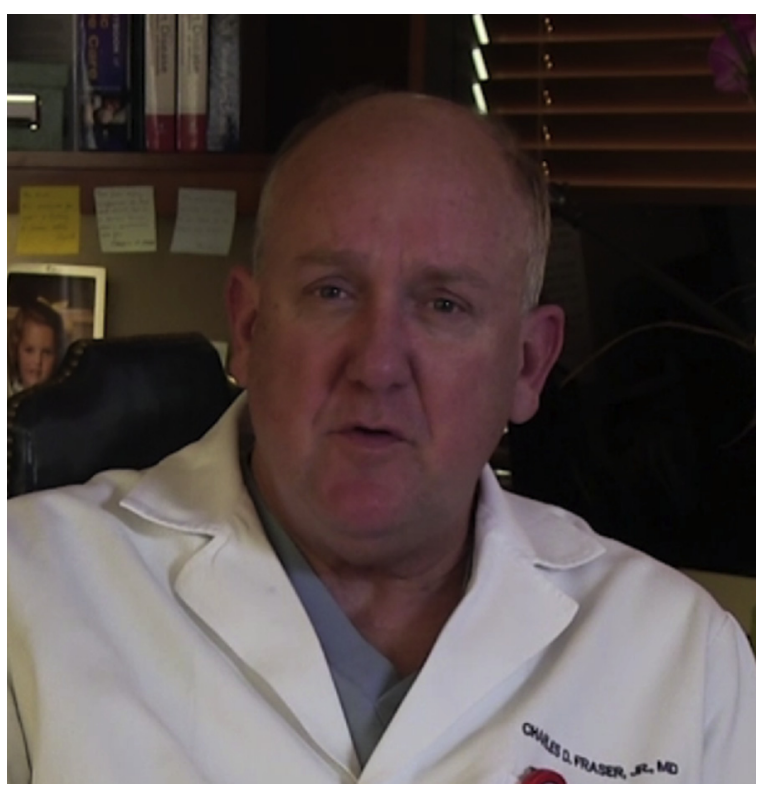

VIDEO 1. Dr Charles D. Fraser, Jr, provides a brief introduction and discusses the most important findings of this study. Video available at: https:// www.jtcvs.org/article/S0022-5223(18)30979-6/fulltext. lower risk for replacement than homografts. ${ }^{20}$ Similar to that study, we have also reported that BJV grafts are associated with a lower rate of reintervention and replacement after adjusting for significant covariates. ${ }^{9}$ Thereby, BJV might still have a role, especially in small patients where a conduit replacement is expected in $<7$ years, small-sized homografts are not readily available, and other stented bioprostheses might be too rigid to use. Despite these potential advantages of BJV grafts, recent studies, including our own institutional experience, have raised the concern regarding the increasing incidence of endocarditis of up to $11.3 \%$ in these grafts. $., 10,12,13,21$

As shown in Figure 1, our institution began to adopt the use of BJV grafts during the first 10 years after it became available. The first 3 cases of endocarditis occurred in 2010, after which the number of infected grafts began to increase. Accordingly, the number of conduits implanted began to decrease, and after our own institutional results were explored in 2015 (published in 2016), which elucidated concise data about the growing incidence of infection of these conduits, our practice shifted toward the use of other available conduits whenever possible.

In our previous report, the incidence of endocarditis among BJV grafts was 6\% (14 conduits), at a median follow-up of 7 years over a 13-year period. ${ }^{9}$ In that report, the use of BJV grafts was associated with a 9 times greater risk of endocarditis compared with that of homografts $(P=.006)$. Calculated estimates suggested that as many as $17 \%$ of patients with a BJV graft would develop endocarditis at 10 years after conduit placement, and that risk seems to increase with time. Since then, after an additional 2.5-year follow-up period, 11 more patients have developed endocarditis, raising the overall incidence of BJV graft endocarditis to $10 \%$, and an estimate of $23 \%$ endocarditis incidence at 10 years of follow-up. During this additional follow-up time, there were no homograft or porcine heterograft conduits that developed infective endocarditis. These findings stand alongside that of other series. Ugaki and colleagues analyzed 244 BJV grafts and 135 homografts with a median follow-up of 3.4 years, and reported that $9.4 \%$ of BJV grafts became infected during the follow-up period, compared with $0.7 \%$ of the homografts. ${ }^{10}$ The highest incidence of BJV graft endocarditis reported in the literature is that of Albanesi et al in Switzerland, with an incidence of $11.3 \%$ over an 11-year period and a median follow-up of 7.6 years. $^{13}$

Various possible hypotheses have been raised for the increased incidence of endocarditis among BJV grafts. Jalal et al reported bacterial adhesion to be higher on the BJV wall for S aureus ${ }^{22}$ and Delmo-Walter et al reported that histologic examination of an explanted BJV graft revealed an acellular homogenous material with fragile, diffuse, and complex collagenization throughout the BJV grafts, and inflammatory tissues. ${ }^{23}$ This might be a result of the 
anticalcification treatment that the conduit undergoes, which might minimize endothelial surface growth. ${ }^{4}$ These factors might contribute to flow turbulence and thrombus formation, increasing the risk of infection. ${ }^{16}$ Somewhat contradictory is the recent report from Veloso et al, who showed similar adherence of 3 bacterial strains to small pieces of bovine pericardial patches, BJV, and cryopreserved homografts, ${ }^{24}$ however, these are in vitro studies using commercially available strains analyzing short-term adhesions, and thereby might not reflect long-term adhesion. ${ }^{25}$ The longevity of the conduit has also been proposed as a substrate for graft endocarditis, with the hypothesis that this complication is more likely to occur the longer the graft remains in place ${ }^{9,10}$; this likely explains why previous studies focused on mid-term outcomes and shorter followup of BJV grafts might have not been able to detect higher rates of endocarditis in these conduits.

Transcatheter pulmonary valve replacement, which is essentially a BJV graft within a stent has raised similar concerns. A large multicenter study showed a $92 \%$ freedom from endocarditis at 4 years. ${ }^{26}$ Van Dijck et al reported a similar 5-year survival free from endocarditis for transcatheter pulmonary valves and BJV grafts $(84.9 \%$ vs $87.8 \%)$, significantly lower than that of homografts $(98.7 \%){ }^{27}$ With increasing use of transcatheter pulmonary valves, the risks associated with these should be further elucidated.

An important finding of the present study is the dramatic increase in incidence of endocarditis after 7.5 years of conduit implantation. This is evidenced in Figure 2, which shows that at 5-year follow-up, there is no significant difference in the number of endocarditis events between conduit types, a freedom from endocarditis estimate of $97 \%$. However, at 7.5 years after conduit implantation, the number of events in the BJV graft group drastically increases, decreasing the 10 -year estimated freedom from endocarditis to $77 \%$, which is significantly different than that of other conduit types.

Such unraveling findings have important implications for patients who have undergone implantation of this grafts. These results warrant increased surveillance in these patients. We suggest that any patient who has undergone implantation of a BJV graft in the past, especially those who have had these grafts in place for more than 6 or 7 years, be followed-up closer and undergo a thorough evaluation by their cardiologists, to detect early signs and symptoms of infection or graft failure, which might be a surrogate for turbulent flow, further increasing the risk of endocarditis. ${ }^{16}$ Furthermore, if a patient presents with malaise or lowgrade fever, there should be a higher index of suspicion for endocarditis in the differential diagnosis, and a more thorough evaluation, including echocardiography and blood culture drawing, should be performed. ${ }^{10,28}$

Another interesting finding in our study is the relative indolent clinical course of the patients who were diagnosed with BJV graft endocarditis. More than $50 \%$ of these patients had low-grade fevers, malaise, and other nonspecific symptoms for several months, with 1 patient having symptoms for up to 6 months. This might have, in some instances, delayed their presentation for evaluation and diagnosis. Looking back at some of these patients, they had even been seen several times by their primary care physicians, before presenting to our institution, and the diagnosis had been missed. This might help explain the median time of symptoms duration of 21 days, which is higher than that reported with other type of infected conduits. ${ }^{9}$

The current American College of Cardiology/American Heart Association guidelines for intervention in patients with infective endocarditis of prosthetic valves recommend early surgical intervention in cases in which valve dysfunction results in symptoms of heart failure, when infection is complicated by heart block, or persistent infection after appropriate antibacterial therapy. ${ }^{29}$ Albanesi et al concluded that surgery was the therapy of choice for infected BJV grafts, with $83 \%$ of their patients undergoing surgical replacement of the infected conduits. ${ }^{13}$ Similar to those findings, in our own series, $92 \%$ of the patients underwent surgical intervention to replace the infected conduit, with no surgical morbidity or mortality. These findings suggest that surgical therapy is a safe and the recommended treatment strategy for these patients. The decision as to which treatment strategy to pursue, as well as the timing of surgical intervention, whenever surgery is the treatment of choice, should be made by a multidisciplinary team including cardiologists, infectious disease specialists, and cardiothoracic surgeons.

\section{Limitations}

This study has multiple limitations, mainly related to its retrospective nature. The number of BJV grafts implanted at our institution decreased in the past 2.5 years, after the findings of our previous study. The present investigation is the result of a single institutional experience and as such, results might vary in different institutions. However, this might also be one of its strengths because the conduit selection, management strategy, and follow-up is more uniform than in retrospective multi-institutional studies.

\section{CONCLUSIONS}

In conclusion, in this large single-institutional cohort, we found a concerning 10\% incidence of late endocarditis affecting BJV grafts, which appears to increase after 7 years of conduit implantation. Because of the increased risk for endocarditis and the relative indolent course of the initial disease, a more adherent and frequent clinical follow-up is warranted in patients who have undergone placement of a BJV graft in the past, especially those who have had a graft in place for more than 7 years. When endocarditis is diagnosed, surgical intervention is a safe strategy, and might alleviate the morbidity and mortality related to endocarditis with excellent outcomes. 


\section{Conflict of Interest Statement}

Authors have nothing to disclose with regard to commercial support.

The authors thank Wei Zhang, $\mathrm{PhD}$, for her support with the statistical analysis and review of the manuscript.

\section{References}

1. Brown JW, Ruzmetov M, Rodefeld MD, Turrentine MW. Right ventricular outflow tract reconstruction in Ross patients: does the homograft fare better? Ann Thorac Surg. 2008;86:1607-12.

2. Sekarski N, van Meir H, Rijlaarsdam ME, Schoof PH, Koolbergen DR, Hruda J, et al. Right ventricular outflow tract reconstruction with the bovine jugular vein graft: 5 years' experience with 133 patients. Ann Thorac Surg. 2007;84:599-605.

3. Rastan AJ, Walther T, Daehnert I, Hambsch J, Mohr FW, Janousek J, et al. Bovine jugular vein conduit for right ventricular outflow tract reconstruction: evaluation of risk factors for mid-term outcome. Ann Thorac Surg. 2006;82:1308-15.

4. Morales DL, Braud BE, Gunter KS, Carberry KE, Arrington KA, Heinle JS, et al. Encouraging results for the Contegra conduit in the problematic right ventricleto-pulmonary artery connection. J Thorac Cardiovasc Surg. 2006;132:665-71.

5. Urso S, Rega F, Meuris B, Gewillig M, Eyskens B, Daenen W, et al. The Contegra conduit in the right ventricular outflow tract is an independent risk factor for graft replacement. Eur J Cardiothorac Surg. 2011;40:603-9.

6. Gist KM, Mitchell MB, Jaggers J, Campbell DN, Yu JA, Landeck BF. Assessment of the relationship between Contegra conduit size and early valvar insufficiency. Ann Thorac Surg. 2012;93:856-61.

7. Christenson JT, Sierra J, Colina Manzano NE, Jolou J, Beghetti M, Kalangos A. Homografts and xenografts for right ventricular outflow tract reconstruction: long-term results. Ann Thorac Surg. 2010;90:1287-93.

8. Boethig D, Thies WR, Hecker H, Breymann T. Mid term course after pediatric right ventricular outflow tract reconstruction: a comparison of homografts, porcine xenografts and contegras. Eur J Cardiothorac Surg. 2005;27:58-66.

9. Mery CM, Guzmán-Pruneda FA, De León LE, Zhang W, Terwelp MD, Bocchini CE, et al. Risk factors for development of endocarditis and reintervention in patients undergoing right ventricle to pulmonary artery valved conduit placement. J Thorac Cardiovasc Surg. 2016;151:432-9. 441.e1-2.

10. Ugaki S, Rutledge J, Al Aklabi M, Ross DB, Adatia I, Rebeyka IM. An increased incidence of conduit endocarditis in patients receiving bovine jugular vein grafts compared to cryopreserved homograft for right ventricular outflow reconstruction. Ann Thorac Surg. 2015;99:140-6.

11. Malekzadeh-Milani S, Ladouceur M, Iserin L, Bonnet D, Boudjemline Y. Incidence and outcomes of right-sided endocarditis in patients with congenital heart disease after surgical or transcatheter pulmonary valve implantation. $J$ Thorac Cardiovasc Surg. 2014;148:2253-9.

12. Boethig D, Schreiber C, Hazekamp M, Blanz U, Prêtre R, Asfour B, et al. Risk factors for distal Contegra stenosis: results of a prospective European multicentre study. Thorac Cardiovasc Surg. 2012;60:195-204.

13. Albanesi F, Sekarski N, Lambrou D, Von Segesser LK, Berdajs DA. Incidence and risk factors for Contegra graft infection following right ventricular outflow tract reconstruction: long-term results. Eur J Cardiothorac Surg. 2014;45:1070-4.

14. Li JS, Sexton DJ, Mick N, Nettles R, Fowler VG, Ryan T, et al. Proposed modifications to the Duke criteria for the diagnosis of infective endocarditis. Clin Infect Dis. 2000;30:633-8.
15. Dave H, Mueggler O, Comber M, Enodien B, Nikolaou G, Bauersfeld U, et al. Risk factor analysis of 170 single-institutional Contegra implantations in pulmonary position. Ann Thorac Surg. 2011;91:195-302; discussion 202-3.

16. Tiete AR, Sachweh JS, Roemer U, Kozlik-Feldmann R, Reichart B, Daebritz SH. Right ventricular outflow tract reconstruction with the Contegra bovine jugular vein conduit: a word of caution. Ann Thorac Surg. 2004;77:2151-6.

17. Pawelec-Wojtalik M, Mrówczyński W, Wodziński A, Wojtalik M, Henschke J, Sharma GK. Mid-term experience with valved bovine jugular vein conduits. Asian Cardiovasc Thorac Ann. 2005;13:361-5.

18. Corno AF, Qanadli SD, Sekarski N, Artemisia S, Hurni M, Tozzi P, et al. Bovine valved xenograft in pulmonary position: medium-term follow-up with excellent hemodynamics and freedom from calcification. Ann Thorac Surg. 2004;78: 1382-8; discussion 1382-8.

19. Breymann T, Blanz U, Wojtalik MA, Daenen W, Hetzer R, Sarris G, et al. European contegra multicentre study: 7-year results after 165 valved bovine jugular vein graft implantations. Thorac Cardiovasc Surg. 2009;57:257-69.

20. Hickey EJ, McCrindle BW, Blackstone EH, Yeh T, Pigula F, Clarke D, et al. Jugular venous valved conduit (Contegra) matches allograft performance in infant truncus arteriosus repair. Eur J Cardiothorac Surg. 2008;33:890-8.

21. Boethig D, Westhoff-Bleck M, Hecker H, Ono M, Goerler A, Sarikouch S, et al. Bovine jugular veins in the pulmonary position in adults -5 years' experience with 64 implantations. Thorac Cardiovasc Surg. 2009;57:196-201.

22. Jalal Z, Galmiche L, Lebeaux D, Villemain O, Brugada G, Patel M, et al. Selective propensity of bovine jugular vein material to bacterial adhesions: an in-vitro study. Int J Cardiol. 2015;198:201-5.

23. Delmo-Walter EM, Alexi-Meskishvili V, Abdul-Khaliq H, Meyer R, Hetzer R. Aneurysmal dilatation of the Contegra bovine jugular vein conduit after reconstruction of the right ventricular outflow tract. Ann Thorac Surg. 2007;83:682-4.

24. Veloso TR, Claes J, Van Kerckhoven S, Ditkowski B, Hurtado-Aguilar LG, Jockenhoevel S, et al. Bacterial adherence to graft tissues in static and flow conditions. J Thorac Cardiovasc Surg. 2018;155:325-32.e4.

25. Mery CM, Fraser CD. Why do some conduits get infected and others don't? J Thorac Cardiovasc Surg. 2018;155:333-4.

26. McElhinney DB, Benson LN, Eicken A, Kreutzer J, Padera RF, Zahn EM. Infective endocarditis after transcatheter pulmonary valve replacement using the Melody valve: combined results of 3 prospective North American and European studies. Circ Cardiovasc Interv. 2013;6:292-300.

27. Van Dijck I, Budts W, Cools B, Eyskens B, Boshoff DE, Heying R, et al. Infective endocarditis of a transcatheter pulmonary valve in comparison with surgical implants. Heart Br Card Soc. 2015;101:788-93.

28. Baddour LM, Wilson WR, Bayer AS, Fowler VG, Bolger AF, Levison ME, et al. Infective endocarditis: diagnosis, antimicrobial therapy, and management of complications: a statement for healthcare professionals from the Committee on Rheumatic Fever, Endocarditis, and Kawasaki Disease, Council on Cardiovascular Disease in the Young, and the Councils on Clinical Cardiology, Stroke, and Cardiovascular Surgery and Anesthesia, American Heart Association: endorsed by the Infectious Diseases Society of America. Circulation. 2005;111:e394-434.

29. Nishimura RA, Otto CM, Bonow RO, Carabello BA, Erwin JP, Fleisher LA, et al. 2017 AHA/ACC focused update of the 2014 AHA/ACC guideline for the management of patients with valvular heart disease: a report of the American College of Cardiology/American Heart Association task force on clinical practice guidelines. Circulation. 2017;135:e1159-95.

Key Words: Contegra, bovine jugular vein, conduit, endocarditis, right ventricular outflow tract 


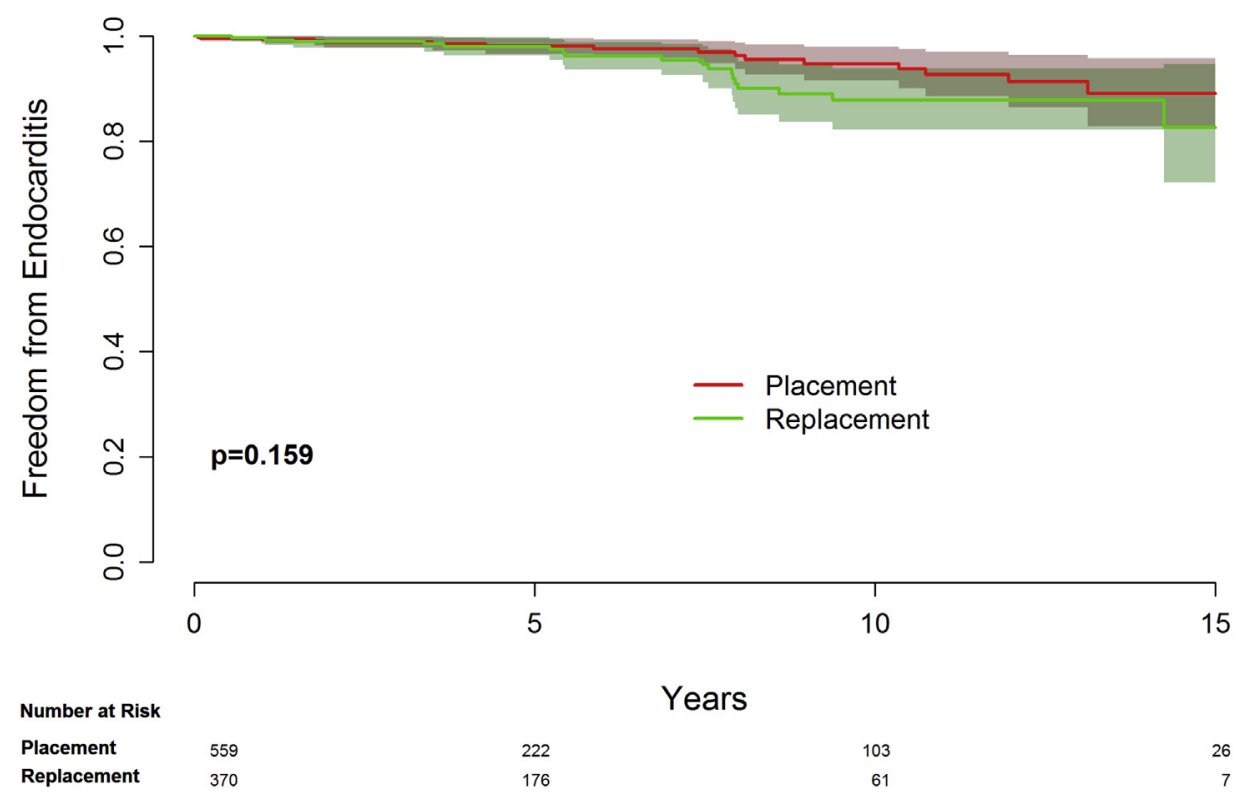

FIGURE E1. Kaplan-Meier curve depicting freedom from endocarditis according to placement and replacement. Those in the placement group are firsttime conduit placement of any type, the replacement includes the second $(n=295)$, third $(n=65)$, fourth $(n=6)$, and fifth $(n=4)$ conduit placed. 
TABLE E1. Characteristics of 25 patients diagnosed with endocarditis of a bovine jugular vein graft conduit

\begin{tabular}{|c|c|c|c|c|c|c|c|c|c|c|c|}
\hline & $\begin{array}{c}\text { Age in } \\
\text { years, } \\
\text { sex }\end{array}$ & Surgery & Fever & $\begin{array}{c}\text { Associated } \\
\text { symptoms (d) }\end{array}$ & $\begin{array}{c}\text { Time to } \\
\text { endocarditis }\end{array}$ & Cultures & $\begin{array}{l}\text { Endocardial } \\
\text { involvement }\end{array}$ & Vegetation & & $\begin{array}{c}\text { Vascular } \\
\text { phenomena }\end{array}$ & $\begin{array}{c}\text { Immunologic } \\
\text { phenomena }\end{array}$ \\
\hline 1 & $19, \mathrm{~F}$ & Yes & Yes & Chills, SOB (21) & $7.9 \mathrm{y}$ & Viridans streptococci & Yes & Yes & Yes & No & No \\
\hline 2 & $15, \mathrm{M}$ & Yes & Yes & $\begin{array}{l}\text { Cough, } \\
\text { congestion (7) }\end{array}$ & $8.5 \mathrm{y}$ & Negative & Yes & Yes & No & No & No \\
\hline 3 & $18, \mathrm{M}$ & Yes & Yes & $\begin{array}{l}\text { Fatigue, jaundice, } \\
\text { shock (21) }\end{array}$ & $6.8 \mathrm{y}$ & $\begin{array}{l}\text { Haemophilus } \\
\text { parainfluenzae }\end{array}$ & Yes & Yes & No & No & No \\
\hline 4 & $16, \mathrm{M}$ & Yes & Yes & $\begin{array}{l}\text { Night sweats, } \\
\text { syncope (30) }\end{array}$ & $14.2 \mathrm{y}$ & Viridans streptococci & Yes & Yes & No & No & No \\
\hline 5 & $13, \mathrm{M}$ & Yes & Yes & Lethargy (28) & $7.8 \mathrm{y}$ & Granulicatella adiacens & Yes & Yes & Yes & Yes & No \\
\hline 6 & $13, \mathrm{~F}$ & Yes & Yes & $\begin{array}{l}\text { Lethargy, decreased } \\
\text { appetite, chills (7) }\end{array}$ & $9.3 \mathrm{y}$ & Viridans streptococci & Yes & Yes & No & No & No \\
\hline 7 & $10, \mathrm{M}$ & Yes & Yes & None (7) & $7.9 \mathrm{y}$ & Viridans streptococci & Yes & No & No & No & No \\
\hline 8 & $15, \mathrm{M}$ & Yes & Yes & Headache (5) & $7.4 \mathrm{y}$ & Viridans streptococci & Yes & Yes & No & Yes & No \\
\hline 9 & $11, \mathrm{M}$ & Yes & Yes & $\begin{array}{l}\text { Vomiting, decreased } \\
\text { appetite (3) }\end{array}$ & $10.3 \mathrm{y}$ & Viridans streptococci & No & No & No & No & No \\
\hline 10 & $14, \mathrm{~F}$ & Yes & Yes & $\begin{array}{l}\text { Malaise, } \\
\text { headache (11) }\end{array}$ & $13.1 \mathrm{y}$ & Viridans streptococci & No & No & No & No & No \\
\hline 11 & $12, \mathrm{M}$ & Yes & Yes & $\begin{array}{l}\text { Cough, chest } \\
\text { pain (7) }\end{array}$ & $5.8 \mathrm{y}$ & Negative & Yes & No & No & No & No \\
\hline 12 & $15, \mathrm{M}$ & Yes & Yes & Cough, syncope (2) & $11.9 \mathrm{y}$ & Negative & No & No & No & No & No \\
\hline 13 & $13, \mathrm{M}$ & Yes & Yes & Vomiting, shock (3) & $7.9 \mathrm{y}$ & $\begin{array}{l}\text { Haemophilus } \\
\text { parainfluenzae }\end{array}$ & Yes & Yes & Yes & No & No \\
\hline 14 & $9, \mathrm{M}$ & Yes & Yes & $\begin{array}{l}\text { Fatigue, } \mathrm{SOB}, \\
\text { congestion, } \\
\text { decreased } \\
\text { appetite (28) }\end{array}$ & $8.9 \mathrm{y}$ & Viridans streptococci & Yes & Yes & No & No & No \\
\hline 15 & $6, \mathrm{M}$ & Yes & Yes & $\begin{array}{l}\text { Abdominal pain, } \\
\text { vomiting (14) }\end{array}$ & $3.5 \mathrm{y}$ & MSSA & Yes & Yes & No & No & No \\
\hline 16 & $9, \mathrm{M}$ & Yes & Yes & $\begin{array}{l}\text { Vomiting, } \\
\text { dizziness (28) }\end{array}$ & $8 \mathrm{y}$ & MSSA & Yes & Yes & No & No & No \\
\hline 17 & $20, \mathrm{~F}$ & Yes & Yes & Cough, rigors (180) & $4.3 \mathrm{y}$ & Cardiobacterium hominis & Yes & Yes & No & No & No \\
\hline 18 & $17, \mathrm{M}$ & Yes & Yes & None (7) & $6 \mathrm{mo}$ & MSSA & Yes & Yes & Yes & Yes & No \\
\hline 19 & $21, \mathrm{~F}$ & No & Yes & $\begin{array}{l}\text { Weakness weight } \\
\text { loss, palpitations, } \\
\text { dizziness (42) }\end{array}$ & $3.6 \mathrm{y}$ & $\begin{array}{l}\text { Viridans } \\
\text { streptococci }\end{array}$ & Yes & Yes & No & Yes & No \\
\hline 20 & & Yes & Yes & $\begin{array}{l}\text { Fatigue, } \\
\text { weakness (45) }\end{array}$ & $7.5 \mathrm{y}$ & Viridans streptococci & Yes & Yes & No & No & No \\
\hline 21 & $14, \mathrm{~F}$ & Yes & Yes & $\begin{array}{l}\text { Cough, abdominal } \\
\text { pain (14) }\end{array}$ & $5.4 \mathrm{y}$ & Viridans streptococci & Yes & Yes & No & No & No \\
\hline 22 & $8, \mathrm{~F}$ & Yes & Yes & None (30) & $7.4 \mathrm{y}$ & $\begin{array}{l}\text { Aggregatibacter } \\
\quad \text { actinomycetemcomitans }\end{array}$ & No & No & No & No & No \\
\hline 23 & $1, \mathrm{~F}$ & No & Yes & None (14) & $34 \mathrm{~d}$ & Viridans streptococci & Yes & Yes & No & No & No \\
\hline 24 & $6, \mathrm{~F}$ & Yes & No & Chills (14) & $5 y$ & Viridans streptococci & No & No & No & No & No \\
\hline 25 & $2, \mathrm{~F}$ & Yes & Yes & SOB, anemia (5) & $1 \mathrm{y}$ & MRSA & Yes & Yes & No & No & No \\
\hline
\end{tabular}

Viridans streptococci include Streptococcus mitis, S sanguis, S mutans, and S parasanguinis. F, Female; SOB, shortness of breath; M, male; MSSA, methicillin-sensitive Staphylococcus aureus; MRSA, methicillin-resistant Staphylococcus aureus. 